\title{
Therapy, diagnosis and prognosis of chronic Chagas disease: insight gained in Argentina
}

\author{
Sergio Sosa-Estani ${ }^{1,2,3} /{ }^{+}$, Rodolfo Viotti ${ }^{4}$, Elsa Leonor Segura ${ }^{2,5}$ \\ ${ }^{1}$ Centro Nacional de Diagnóstico e Investigación de Endemo-epidemias ${ }^{5}$ Instituto Nacional de Parasitología Dr. Mario Fatala Chaben, \\ ANLIS Dr. Carlos G. Malbrán, Ministerio de Salud, Buenos Aires, Argentina ${ }^{2}$ Consejo Nacional de Investigaciones Científicas y Técnicas, \\ Buenos Aires, Argentina ${ }^{3}$ Instituto de Efectividad Clínica y Sanitaria, Buenos Aires, Argentina ${ }^{4}$ Hospital Eva Perón de San Martín, \\ Buenos Aires, Argentina
}

The purpose of this review is to describe research findings regarding chronic Chagas disease in Argentina that have changed the standards of care for patients with Trypanosoma cruzi infection. Indirect techniques (serological tests) are still the main tools for the primary diagnosis of infection in the chronic phase, but polymerase chain reaction has been shown to be promising. The prognosis of patients with heart failure or advanced stages of chagasic cardiomyopathy is poor, but a timely diagnosis during the initial stages of the disease would allow for prescription of appropriate therapies to offer a better quality of life. Treatment of T. cruzi infection is beneficial as secondary prevention to successfully cure the infection or to delay, reduce or prevent the progression to disease and as primary disease prevention by breaking the chain of transmission. Current recommendations have placed the bulk of the diagnostic and treatment responsibility on the Primary Health Care System. Overall, the current research priorities with respect to Chagas disease should be targeted towards (i) the production of new drugs that would provide a shorter treatment course with fewer side effects; (ii) the development of new tools to confirm cure after a full course of treatment during the chronic phase and (iii) biomarkers to identify patients with a high risk of developing diseases.

Key words: Chagas disease - Trypanosoma cruzi - diagnosis - prognosis - treatment

One hundred years after Carlos Chagas identified and described infection with Trypanosoma cruzi, there are still millions of people infected with it, and thousands of new cases of Chagas disease (CD) are being diagnosed each year. The scientific community, although in an intermittent manner, has increased the knowledge and understanding of how to manage patients with chronic CD infection (PAHO 2005). Nonetheless, much research is still needed to improve care and to answer many of the unknown questions regarding this debilitating and widespread disease. In the Americas, there are approximately eight million patients suffering from the chronic phases of CD (PAHO/WHO 2006). Myocarditis secondary to $\mathrm{CD}$ is the most common form of non-ischemic cardiomyopathy worldwide (Feldman \& McNemara 2000). CD can also result in other manifestations, such as pathologies in the gastrointestinal tract (megaesophagusandmegacolon)ordisorders of the central and peripheral nervous system. Clinical manifestations of the chronic phase were extensively described a century ago by Carlos Chagas (Chagas 1911). The most recent figures provided by the World Health Organization indicate that about two million infected individuals have cardiomyopathy (PAHO/WHO 2006).

+ Corresponding author: ssosa@msal.gov.ar

Received 24 March 2009

Accepted 8 June 2009
Currently, the main challenges related to the control of $\mathrm{CD}$ lie in three areas: (i) consolidating and maintaining control of endemic disease by implementing sustainable epidemiological surveillance programs; (ii) providing effective medical care and social attention to individuals who are already infected and (iii) conducting research to support and guide the first two tasks. For example, studies are needed to produce better surveillance tools, to develop new anti-parasitic drugs and to establish better management plans for disease manifestations (including heart disease and other manifestations) (Pinto Dias 2006).

The goal of specific treatment for T. cruzi infection is to eliminate the parasite from the infected individual, to decrease the probability of developing illness (CD) and to break the chain of disease transmission (Sosa-Estani \& Segura 2006). In this paper, we present the experiences and contributions, of primarily Argentinean researchers and others, regarding therapy, diagnosis and prognosis of patients in the chronic phase of infection with T. cruzi.

We conducted a review based on MEDLINE searches using the term "Chagas disease" with the subheadings diagnosis, prognosis, treatment, drug names (nifurtimox, benznidazole) and clinical trials. Recent guidelines by expert committees were also consulted.

\section{Diagnosis of infection in the chronic phase}

Without treatment and independent of the route of transmission, the natural history of $\mathrm{CD}$ is a decrease in parasitemia 90 days after infection to the point that the parasite is undetectable by direct microscopy. From this phase on, the primary method for diagnosis is serologi- 
cal testing, while the secondary diagnostic techniques are parasitological tests.

Serological methods underwent intensive development in Argentina during the 1960s and 1970s, resulting in the development of complement fixation (Muniz \& Freitas 1944, Cerisola \& Rosembaum 1958), the indirect immunofluorescence assay (IFA) (Alvarez et al. 1968), and the indirect hemagglutination assay (IHA) (Cerisola et al. 1962, Vattuone \& Yanovsky 1971). Furthermore, during the 1980s, the enzyme immune assay (EIA) was added as another serological test using known recombinant antigens (Cura et al. 1993, Caballero et al. 2007). At the end of the 1960s, Cerisola et al. (1969) suggested the use of at least two different serologic tests to establish $\mathrm{CD}$ diagnosis. Specifically, guideline recommendations were to perform a third assay or repeat sampling to confirm or exclude the diagnosis if two serological tests were in disagreement (WHO 2002). During the 1980s, intense collaborative efforts resulted in a regional consensus for diagnosis and treatment (Camargo et al. 1986).

Other methods, such as rapid tests that screen for anti-T. cruzi antibodies in whole blood and serum using the immunochromatographic screening test, have been assessed and have been found to have varying degrees of performance (Luquetti et al. 2003, Ponce et al. 2005, Sosa-Estani et al. 2008). Programs to conduct population-based screening have been successful in diagnosing more cases in the chronic phase (Rosembaum \& Cerisola 1961, Segura et al. 2000, Sosa-Estani 2005).

Parasitological tests such as xenodiagnosis (Cerisola et al. 1971), haemoculture (Abramo Orrego et al. 1980) and, more recently, the detection of parasite DNA using polymerase chain reaction (PCR) (Avila et al. 1991, Britto et al. 1995, Silber et al. 1997, Schijman et al. 2000) are useful during the chronic phase of T. cruzi infection, although these methods are significantly less sensitive than serological testing for diagnosis during the chronic phase. The xenodiagnosis method that has been used for decades (Pedreira de Freitas 1950, Schenone et al. 1968, Cerisola et al. 1971 ) is now practically restricted to use in isolating parasites in research laboratories due to its complexity. Assays based on PCR, which detect T. cruzi nucleic acids, have proven to be useful for verification of parasite persistence in the host, particularly for the assessment of the effectiveness of antiparasitic treatment (Britto et al. 1995, Schijman et al. 2000, 2003). Currently, a process to standardise and validate PCR for clinical use in $\mathrm{CD}$ is being investigated under the coordination of TDR-WHO (TDR 2008).

Identification of parasites by microscopy, haemoculture or PCR-based methods provides a definitive diagnosis of CD. However, the level of parasitemia required for detection by these methods limits their sensitivity and a negative result does not confirm a negative diagnosis. Even current, first-line diagnostic tools for the primary diagnosis of infection in immunocompetent individuals in the chronic phase mainly use indirect techniques (for example, detection of antibodies by a serological test). It is necessary to develop tools with a high sensitivity that can demonstrate the presence of the parasite during the chronic phase of CD.

\section{Prognosis of the chronic chagasic cardiomyopathy}

Chagasic cardiac disease has been intensively studied in Argentina in both clinical and epidemiological studies (Rosenbaum \& Cerisola 1961, Rosenbaum 1964, Chiale et al. 1984, Lazzari et al. 1998).

The prognosis of patients with heart failure or advanced stages of chagasic cardiomyopathy is poor (Rassi et al. 2006), but similar to the prognosis of patients who develop heart failure for other reasons. Because the disease is chronic and heart damage develops over decades, it is very important to recognise factors that are determinants of disease progression in the early stages (Viotti et al. 2005). Indicators of risk or progression of chronic chagasic cardiomyopathy can be divided into clinical, serological and socioeconomic categories.

Clinical indicators - Several clinical studies in Argentina have contributed to the clinical detection of disease, demonstrating techniques to differentiate between the prognoses of patients without obvious heart disease and those with mild chagasic cardiomyopathy. Clinical studies with long-term cohorts of patients have been able to detect and determine disease severity and progression according to serology reactivity, electrocardiographic (ECG) changes and chest X-ray or echocardiogram findings.

Of the different classifications, the Kuschnir classification (Kuschnir et al. 1985) has been the most commonly used. It includes the following categories: Group 0 : reactive serology, normal ECG and normal chest $\mathrm{x}$-ray/ echocardiogram; Group I: reactive serology, abnormal ECG and normal chest x-ray/echocardiogram; Group II: reactive serology, abnormal ECG and increased cardiothoracic index or left diastolic diameter by chest x-ray/ echocardiogram, but without signs or symptoms of heart failure and Group III: reactive serology, abnormal ECG and an increased cardiothoracic index or left diastolic diameter by chest $\mathrm{x}$-ray/echocardiogram with signs and/ or symptoms of heart failure.

ECG changes or new ECG abnormalities during clinical follow-up are the simplest and therefore the most commonly used, tool in medical care and clinical research. Although chronic CD may be the probable etiology of some of the abnormal findings, there are other common ECG disorders in the seronegative population of the same age group (Viotti et al. 1994). Therefore, if ECG monitoring is to be used as the primary tool for disease detection and progression, ECG abnormalities that are considered a sign of Chagas heart disease are clearly defined: (i) complete right bundle branch block and left anterior fascicular block; (ii) complex ventricular arrhythmias and sustained ventricular tachycardia; (iii) supraventricular tachyarrhythmias (atrial fibrillation, atrial flutter and atrial tachycardia); (iv) second degree type II and complete A-V blocks; (v) sinus bradycardia $<50$ beats per minute and (vi) the presence of a permanent pacemaker.

ECG abnormalities probably unrelated to $\mathrm{CD}$ include the following: (i) incomplete right bundle branch block; (ii) disorders of ventricular repolarisation; (iii) isolated supraventricular and ventricular premature contractions; (iv)first degree and second degree type I A-V blocks and (v) sinus bradycardia $<50$ beats per minute. 
Other clinical indicators can be detected by echocardiography (i.e., enlargement of left ventricular diameters, global systolic dysfunction and E-point septal separation) (Viotti et al. 2004, Petti et al. 2008) or by exercise stress testing (assessment of ventricular arrhythmias) (Viotti et al. 2006b).

The main clinical prognostic factors identified in $\mathrm{CD}$ include the following: (i) electrical conduction abnormalities (right bundle branch block and left anterior fascicular block) are associated with a two-fold increase in the likelihood of disease progression compared to patients without such ECG abnormalities (Viotti et al. 2005); (ii) an increase in left ventricular diastolic and systolic diameters detected by echocardiography also predicts a two-fold increase in the likelihood of progression of heart disease (Viotti et al. 2004) and (iii) severe systolic dysfunction and E-point septal distance greater than $20 \mathrm{~mm}$ predict the onset of heart failure in patients with previous asymptomatic left ventricular dysfunction (Petti et al. 2008).

History of an episode of sustained ventricular tachycardia indicates a three-fold increase in the likelihood of CD progression (Viotti et al. 2005).

Ventricular arrhythmias during stress testing were also predictors of worsening disease from a clinical point of view (Viotti et al. 2006b).

A clinical score based on the risk of progression of heart disease has shown an adequate capacity to differentiate varying prognoses of patients with chronic $\mathrm{CD}$ (Viotti et al. 2005).

Serological indicators - The persistence of three reactive conventional serological tests over 10 years or more of follow-up is related to a greater likelihood of progression of heart disease than the likelihood of heart disease progression associated with patients who have a partial or complete negative seroconversion. This usually happens after treatment of the underlying infection but, in a few cases, has happened spontaneously (Viotti et al. 1994, 2006a, Gallerano \& Sosa 2000, Fabbro et al. 2007).

A decrease in the level of antibody titres seems to precede conversion to seronegativity and has the same meaning from a clinical point of view, although both require long-term serological follow-up.

Socioeconomic indicators - There are few publications that assess socioeconomic indicators; however, the general consensus of researchers supports the concept that having low socioeconomic status is a major factor in the emergence, evolution and progression of $\mathrm{CD}$ (Viotti et al. 2008). Patients who do not complete a primary education have a higher rate of disease progression than those who complete more education (Fig. 1A). A shorter time of residence within an endemic area or at the house where the infection was acquired can facilitate the conversion to seronegativity and better clinical outcomes, possibly due to the lower chance of re-infection and, consequently, a lower parasitic load (Storino et al. 2002). In addition, economic indicators that are associated with the persistence and activity of urban chronic CD include overcrowding and a lack of health insurance (Viotti et al. 2008).
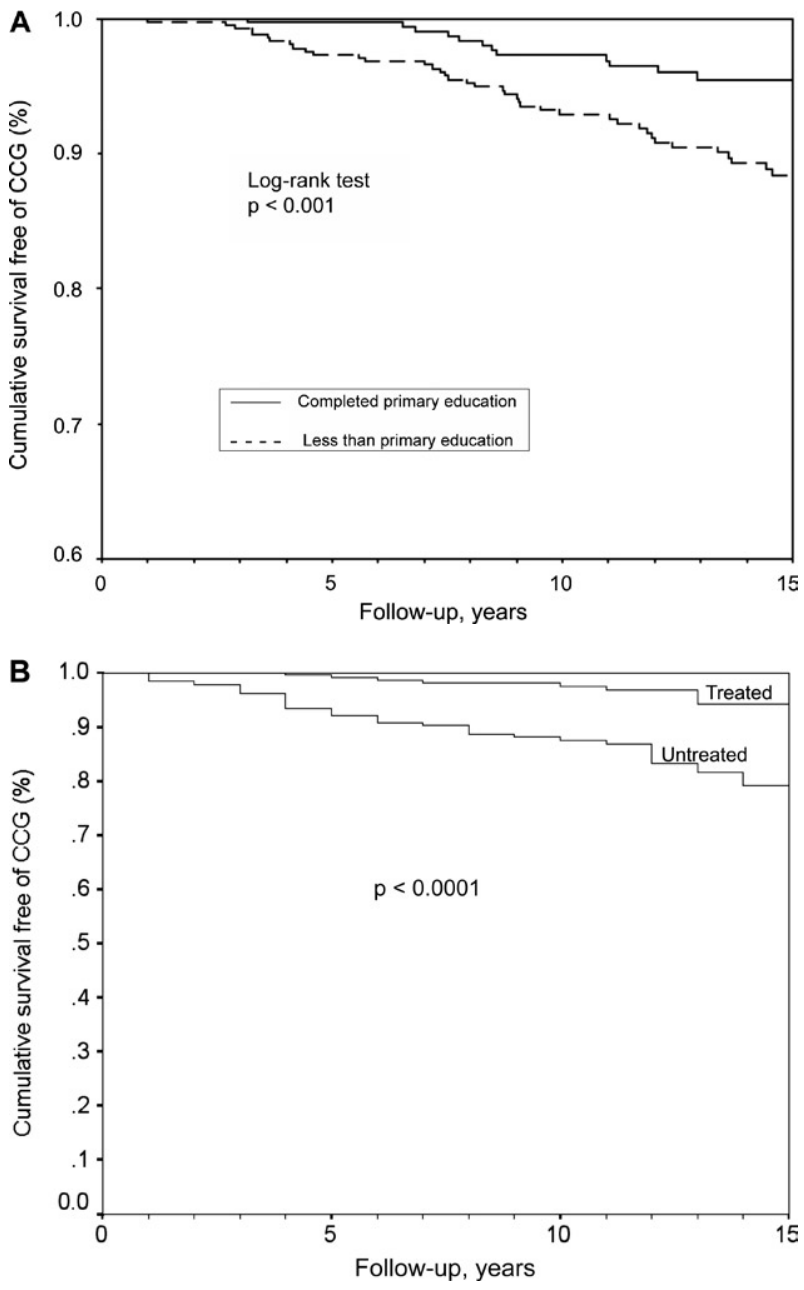

Fig. 1A: Kaplan-Meier curve of survival-free-of-change of clinical group of patients with and without primary education (Viotti et al. 2008); B: Kaplan-Meier curve of survival-free-of-change of clinical group of patients with and without treatment with benznidazole. CCG denote changes of clinical group (Viotti et al. 2006a).

\section{Biomarkers of progression}

Biomarkers to predict the progression to disease are considered a priority area of research in CD (TDRWHO 2005). To date, studies have demonstrated both increased titres of s-VCAM-1 and s-P-selectin and a positive association between disease severity and levels of s-P-selectin in chronically infected patients (Laucella et al. 1996).

Similarly, research on specific immunity has shown that the frequency of IFN-gamma-producing T cells in patients with chronic $\mathrm{CD}$ is associated with a history of recent exposure and the clinical picture where responses to a parasite lysate revealed a very high frequency of responders among patients with mild clinical disease and a very low frequency of responders among those with the most severe form of the disease (Laucella et al. 2004). An analysis of CCR7 expression revealed a significant increase in total effector/memory $\mathrm{CD}^{+} \mathrm{T}$ 
cells in subjects with mild heart disease compared with uninfected controls. These results are consistent with the hypothesis of a gradual clonal exhaustion in the $\mathrm{CD} 8^{+}$ $\mathrm{T}$ cell population, perhaps as a result of continuous antigenic stimulation by persistent parasites (Albareda et al. 2006). On the other hand, the specific response has also been shown to select for sublineage clones of $T$. cruzi leading to the development of chagasic cardiomyopathy (Venegas et al. 2009). Several studies have revealed a positive association between tissue parasitism and the severity of inflammation. Furthermore, some researchers consider the presence of parasites in heart tissue to be necessary for maintaining an inflammatory response causing tissue damage (Marin-Neto et al. 2007).

Other studies looking at biomarkers have found autoantibodies that are reactive against the second extracellular loop of the human heart beta-1 adrenoceptor and the M2 cholinoceptor by testing with synthetic peptides using immunoblotting and EIAs. Also, the corresponding affinity-purified anti-peptide antibodies displayed an agonist-like activity associated with specific receptor activation. A strong association has been demonstrated in patients with chronic disease between circulating anti-peptide M2 mAChR autoantibodies and the presence of a low heart rate variability index, bradycardia and cardiac or esophageal autonomic dysfunction. These findings suggest that the anti-peptide antibodies are suitable biomarkers for cardiac neuromyopathy and achalasia (Sterin-Borda \& Borda 2000, Gazinelli et al. 2008).

\section{Etiological treatment}

In 1937, Salvador Mazza tested bisquinaldine and demonstrated its anti-T. cruzi activity. Since then, several other compounds have been tested with the intent of finding alternative treatments for $T$. cruzi infection (Sosa-Estani \& Segura 1999). At the end of the 1960s, an international clinical trial was conducted to assess the efficacy of nifurtimox and benznidazol (generic names). Several researchers had recommended administering treatment during the acute phase and in the chronic phase (Cerisola 1977). In Argentina, it was recommended that all infected patients should receive treatment and that all immigrants should be tested and treated if infected. During that time, nifurtimox was the drug of choice. However, in 1983, a panel of experts reversed these recommendations, suggesting that treatment not be administered during the chronic phase of infection (Brener 1984). The concept that cardiac manifestations of the chronic phase of $\mathrm{CD}$ were unrelated to the presence of $T$. cruzi was then widespread in the international medical community (Cossio et al. 1974). The change in perspective on this issue in the 1980s arose from several sources: (i) the hypothesis of an autoimmune pathogenesis of chronic Chagas heart disease (Cunha-Neto at al. 1995, Kierszenbaum 1999); (ii) poor and inconsistent findings of circulating parasite in blood samples and (iii) an absence of clinical or biological indicators of the treatment efficacy of anti-parasitic drugs for short and medium courses (Cançado 1999). Twenty years of silence in research endeavors directed at CD ensued as a result of this shift in paradigm about the usefulness of these drugs to treat patients in the chronic phase. The indications for anti-parasitic treatment in the chronic phase have remained controversial for many years.

There were, however, pockets of persistent use of drugs, mostly benznidazole rather than nifurtimox, during the 1980s, and follow-up studies have shown effectiveness during the chronic phase. During the 1990s, long-term follow-up was carried out mainly by observational studies (Viotti et al. 1994, 2006a, Moretti et al. 1998, Gallerano \& Sosa 2000, Fabbro at al. 2007) and two randomised clinical trials in children were also performed (de Andrade et al. 1996, Sosa-Estani et al. 1998).

\section{Effectiveness against infection (secondary preven- tion level)}

Studies assessing efficacy against infection are summarised in Table I. Demonstration of anti-parasitic effects after treatment can be performed by the detection of antibodies, parasites and/or parasite DNA. The success of the treatment is determined by the disappearance of antibodies using serological tests, while therapeutic failure is determined by the persistence of the parasite using parasitological methods. The following must also be considered for monitoring treatment success: (i) the age of the patient when he/she received the treatment; (ii) the time elapsed between treatment and follow-up and (iii) the region where the patient was infected (SosaEstani \& Segura 2006).

For example, when trypanocidal treatment is used for adult patients in the late chronic phase, no decrease in antibody titre is observed at short-term follow-up (Cerisola 1977, Cançado 2002), while long-term follow-up studies have shown higher serological negativization rates (Moretti et al. 1998, Viotti et al. 2006a, Fabbro et al. 2007). A decline in antibody titres may be seen after five or more years depending on the age of the patient when treatment was received and the length of the period between treatment and testing. "Cure" rates (negative serologies) of $8-40 \%$ have been reported in the late chronic phase in adult patients by investigators who were able to follow up for a long period of time (about 10-20 years) (Moretti et al. 1998, Gallerano \& Sosa 2000, Viotti et al. 2006a, Fabbro et al. 2007). Conversely, the rate of serological negativisation (effectiveness) can reach up to $70 \%$ in children (early chronic infection) (de Andrade et al. 1996, Russomando 1998, Sosa-Estani et al. 1998, 2002, Streiger et al. 2004).

The fall in antibody titres after treatment in children is faster than in adults, even if this fall does not cross the cut-off to become considered non-reactive. The decrease in antibody titres is significant during the early months after treatment, three months to EIA and IFA, and six month IHA (de Andrade et al. 1996, Sosa-Estani et al. 1998). Young children with longer term follow-up have higher rates of seroconversion after treatment than children with short-term follow-up and a similar result is found when comparing the seroconversion rates of adult patients with longer term follow-up and the rates of adult patients with short-term follow-up (Fig. 2A). In summary, the age of the patient when treated and the length of 
follow-up are fundamental considerations in the assessment of the treatment efficacy.

Others methodologies to evaluate the effectiveness of anti-parasitic treatments have been tested by several groups in Argentina and in other countries in the Americas. The following is a list of some of these methodologies: (i) lytic antibodies (Galvão et al. 1993); (ii) recombinant antigens (Krautz et al. 1995, Sosa-Estani et al. 1998, Altcheh et al. 2003, Sanchez-Negrete at al. 2008); (iii) purified mucin-like glycoconjugate from cell-cultured trypomastigotes or flagellar antigen for serological tests (de Andrade et al. 1996, Moretti et al. 1998, Almeida et al. 1999); (iv) monitoring plasma levels of the adhesion molecule p-selectin (Laucella et al. 1999) and (v) specific cellular immune response to interferon gamma (Laucella et al. 2004). All of these have been published, but a consensus has not yet been reached to change the current testing strategy.

The gold standard to assess response to specific treatments remains the detection of free parasites in the patient's blood (Cerisola et al. 1971) or tissues (Schijman et al. 2004), which permits clear observation of failure of treatment. In the past, xenodiagnosis was the main test used to test for circulating parasites (Cerisola et al. 1977). Several studies have indicated that the rates of positive xenodiagnostic testing in children and adults were no more than 5-10\% after treatment (Cerisola 1977, Viotti et al. 1994, Sosa-Estani et al. 1998, Streiger et al. 2004, Fabbro et al. 2007). However, Gallerano and Sosa (2000) showed a higher rate of positive xenodiagnostic testing when they used benznidazol, nifurtimox or allopurinol. However, this drug (allopurinol) did not show consistent results when tested in clinical trials (Sánchez et al. 2005, Rassi et al. 2007). An evaluation of pre and post-treatment with benznidazole carried out with haemocultures showed an efficacy of $89 \%$ in adults treated in the ongoing chronic phase of infection (de Castro et al. 2006), reiterating what was shown in other trials using xenos testing.

The sensitivity of xenos (if applied only once) in patients during the chronic phase before treatment is around 30\% in adult patients (Schenone et al. 1968) and $50 \%$ in children (Sosa-Estani et al. 1998). After treatment, the range of positive xenos is from $0-5 \%$ (Fig. 2). If we apply the same xenos sensitivity rate after treatment, we can assume a failure rate between 1-30\%.

Five randomised clinical trials using anti-trypanosomal drugs showed a beneficial effect on serological conversion of patients with chronic CD. Overall, benznidazole reduced the proportion of positive xenos in both children and adults by about $80 \%$ and led to an 11-fold increase in the rate of negative seroconversion (Villar et al. 2002).

Methods to detect the parasite's genomic fragments in tissues and body fluids using PCR have proved to be promising tools for the assessment of therapeutic effectiveness (Britto et al. 1995, Solari et al. 2001, Galvão et al. 2003, Schijman et al. 2003, Sánchez et al. 2005, Duarte et al. 2006, Diez et al. 2007). There is consensus that, even with limitation, it will be a useful tool to improve the assessment of treatment efficacy. The PCR technique has shown greater rates of effectiveness over a given follow-up period than conventional serology. Ad-
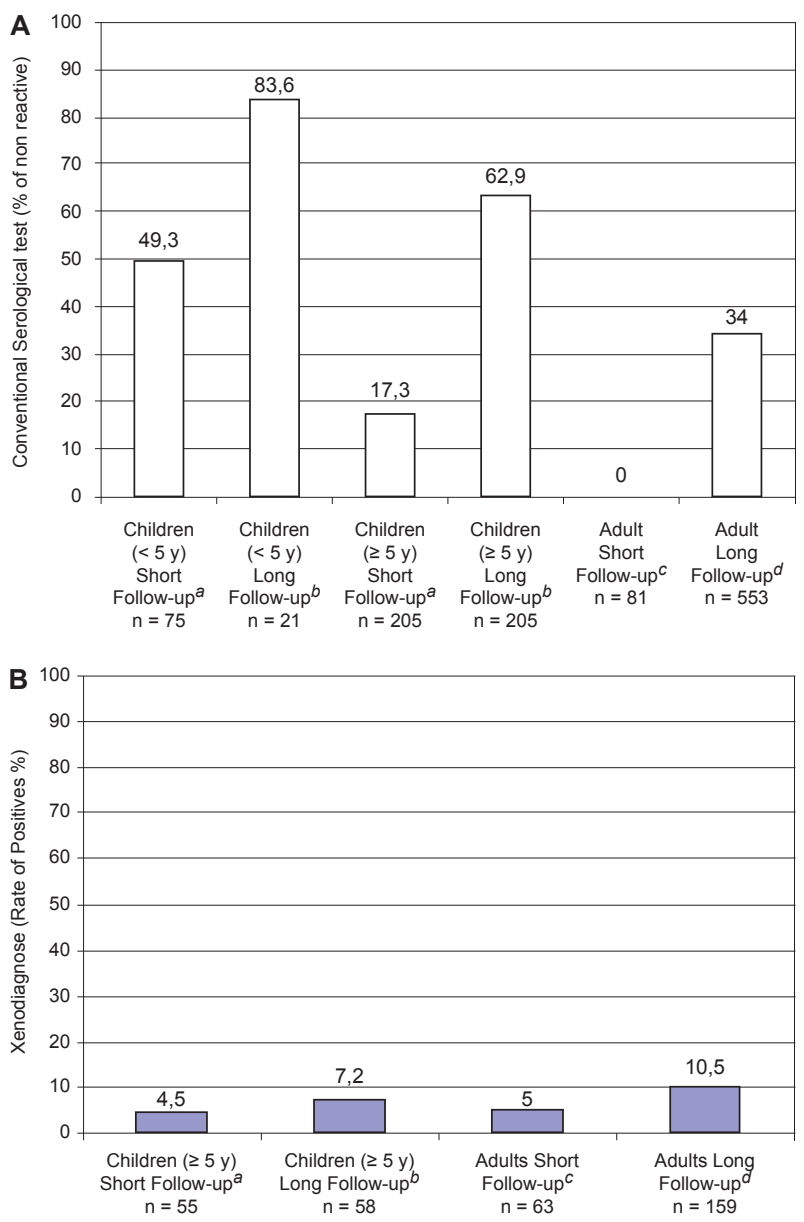

Fig. 2A: percentage of patients with serological test non-reactive (cure) after treatment. Patients infected (children and adults) treated, controlled short and long term of follow-up (source: references of Table I); B: percentage of patients with xenodiagnosis positive (failure) after treatment. Patients infected (children and adults) treated, controlled short and long term of follow-up (source: references of Table I). $a$ : $<5$ years of follow-up; $b: \geq 5$ years of follow-up; $c:<10$ years of follow-up; $d: \geq 10$ years of follow-up.

ditionally, this technique may provide an opportunity to shorten the evaluation period for trypanocidal treatment effectiveness (Sosa-Estani \& Segura 2006). More recently, a cross-sectional study has shown a significant decrease in IFN-gamma-producing $\mathrm{T}$ cells specialised for a $T$. cruzi lysis in a treated patient group compared to a non-treated group (Laucella et al. 2004). Although more research is needed, the detection of this specific immune response after treatment could be useful as a complementary measure to the detection of antibodies, parasites and parasite DNA to access treatment (Bustamante et al. 2008).

Prior determinations of therapeutic success have been based on demonstrating disappearance of antibodies using serological tests. Therapeutic failure, conversely, is associated with the persistence of parasite detection using parasitological testing (Sosa-Estani \& Segura 2006). If parasite persistence is identified and correct drug administration is verified, it is necessary to consider the 


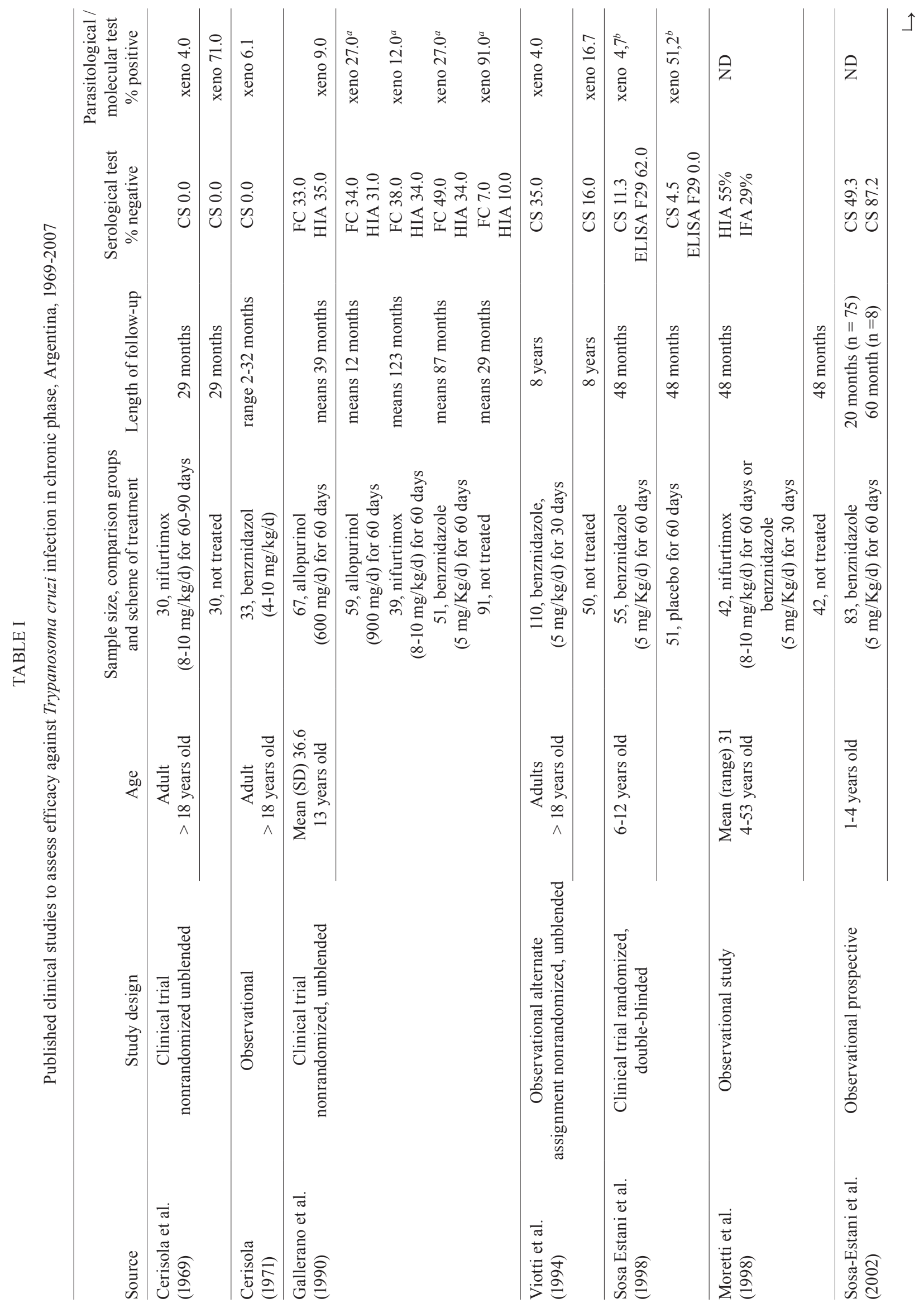




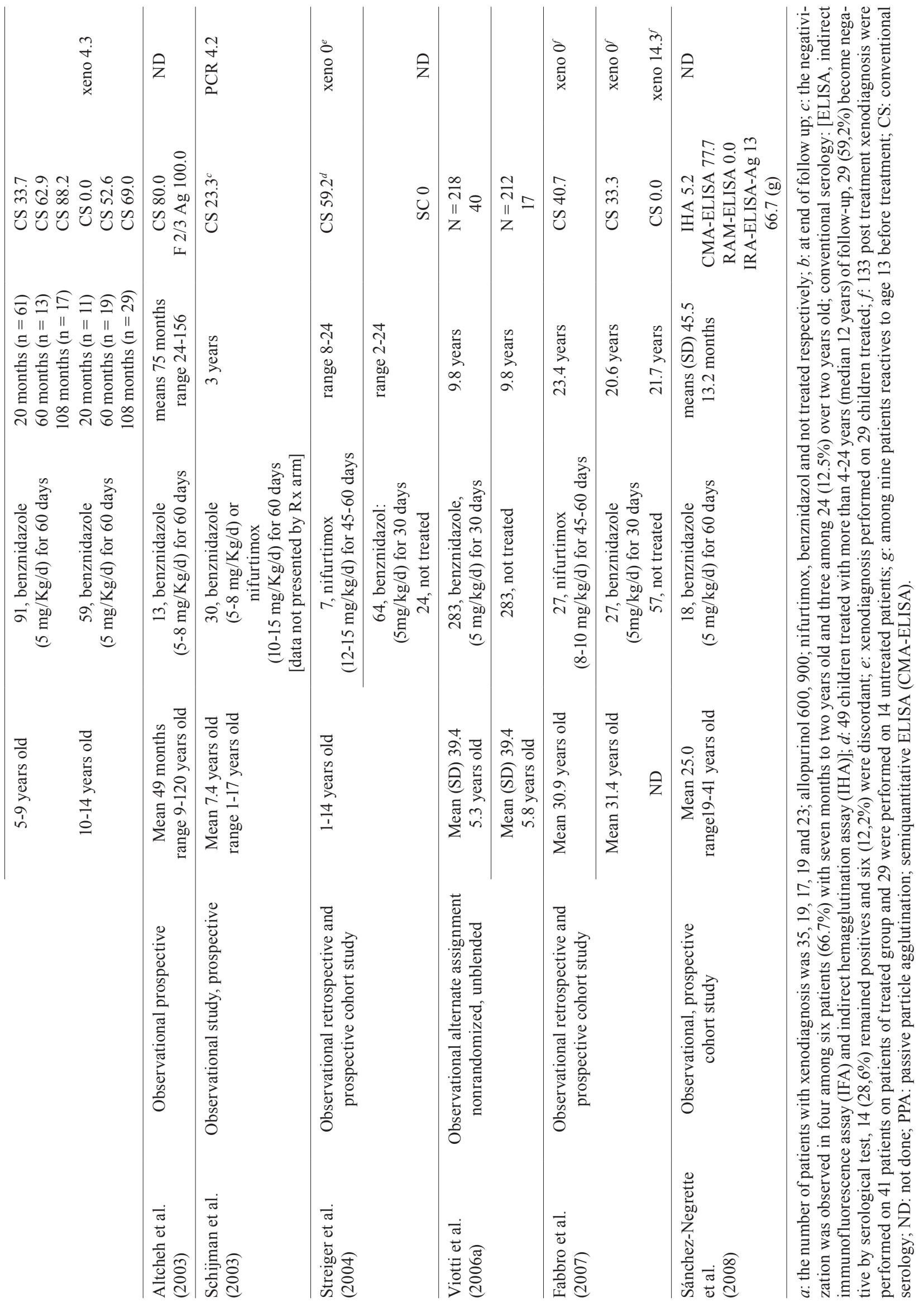


possibility that the parasite has developed resistance (Murta et al. 1998, Dos Santos et al. 2008)

The demonstration of treatment failure of one of the available drugs (benznidazole or nifurtimox) in patients with acute illness requires the use of the other medication (MSA 2006). There is no evidence if this strategy is beneficial in patients in the chronic phase.

Possible regional differences (host, T. cruzi strain etc.) have also been described (Cerisola 1977). Recent studies suggest that the amount of the time lapsed before it is possible to demonstrate a cure in children using serological tests shows regional differences and cure can be detected earlier in Central America and the northern regions of South America, including the Amazon Region (Morote et al. 2008) than in can be detected in the Southern Cone of America (de Andrade et al. 1996, Sosa-Estani et al. 1998, Streiger et al. 2004).

After etiologic treatment, even in cured patients, antibodies remain for a long period of time (years) before becoming negative. Because of this phenomenon, it will be necessary to introduce a question regarding "whether he/she received treatment in the past" when taking a history from a patient with reactive serology. Given an affirmative answer, we must consider whether this reactivity is an active infection or if the patient is in the process of becoming negative.

\section{A change of paradigm in chronic disease: current treatment recommendations}

In 1994, two studies almost simultaneously demonstrated clear findings that the T. cruzi parasite was likely to be responsible and important in the development of cardiomyopathy. One clinical study described the simultaneous reduction of ECGphic changes and halted progression of heart disease after $\mathrm{CD}$ treatment that reduced antibody titres or resulted in seronegative conversion (Viotti at al. 1994). The other study was the first to describe the technique using PCR to detect the presence of T. cruzi DNA in cardiac tissue of chronic chagasic patients (Jones et al. 1993). These studies were the precursors of a new hypothesis regarding the development of CD-related cardiomyopathy, since they demonstrated an important role of the etiological agent in the abnormal immune response and its persistence (Zhang \& Tarleton 1999).

Several clinical studies in Argentina that compared the disease evolution of treated and untreated patients have shown a reduction of as much as $75 \%$ in the progression of heart disease in the treated patients. Similar results have been described in other countries as well (Fragata Filho et al. 1995, Apt et al. 2005). However, some researchers have not observed differences between treated and untreated patients (Storino et al. 1998, Lauria-Pires et al. 2000, Manzullo 2001). The main results of the experience in Argentina related to the treatment of adult patients with chronic $\mathrm{CD}$ are summarised in Table II.

The pathogenesis of chronic chagasic cardiomyopathy is still not completely understood, although the persistence of $T$. cruzi leading to inflammation and changes in the host's immune response appear to be the key factors in the progression to myocardial damage.
An integrated pathogenic interpretation of chronic chagasic myocarditis should explain (i) why the presence of small parasite fragments is necessary for the production of lesions; (ii) the molecular process that induces lesions in situ; (iii) the mechanisms of inflammation at both the cellular and molecular level and (iv) the immunological and non-immunological mechanisms that amplify myocarditis. The relationships between (i) persistent parasite levels, (ii) the immunological status of the host and (iii) the phenotypic characteristics of the parasite strains as possible determinants of the magnitude of cardiac lesions are likely to be determined in the near future. In the meantime, CD should be treated as a parasitic disease with the primary objective being to reduce the parasite load in order to improve the effectiveness of the immune response and to reduce disease progression to cardiomyopathy (Fig. 1B). These experiences and the consensuses of expert opinions that have recently been published as both guides and treatment protocol updates in different countries (Sosa-Estani \& Segura 2006, Bern et al. 2007, Gascón et al. 2007) maintain that etiological treatment should be offered to all patients with reactive anti-T. cruzi serology until 50 years of age. Two randomised clinical trials are in progress to confirm the present accumulation of evidence (Reyes \& Vallejo 2005, Riarte et al. 2005, Marin-Neto et al. 2008).

\section{Tolerance and adherence}

During treatment, patients must be under continuous medical supervision. In our experience, treatment tolerance has been good and patients have not demonstrated serious side effects (Viotti et al. 1994, 2006a, Sosa-Estani et al. 2002, 2004). Although cases with severe side effects have been reported, they have generally been associated with difficulties in seeking timely medical attention or receiving adequate care. It is known that both treatment drugs have significant side effects, including anorexia, vomiting, peripheral polyneuropathy, bone marrow depression and allergic dermatitis; consequently, treatments must be discontinued when side effects are noted. Laboratory tests showed normal bilirubin values, with rare cases of elevated transaminases (Sosa-Estani et al. 1998, 2004). Side effects are more frequently observed in adolescents and adults than in children and babies. In all cases, side effects disappeared when the dose was decreased or the treatment suspended. After 15 years of follow-up, the children who did experience side effects and who underwent clinical examination did not show any pathological signs or symptoms associated with the event.

Reversible clastogenesis and mutagenesis with benznidazole and nifurtimox without any associated manifestations have been reported (Moya \& Trombotto 1988, Gorla et al. 1989). Conversely, toxicity has been described in other tissues (de Mecca et al. 2008). For instance, an increased risk of lymphomas was found in experimental animals (Teixeira et al. 1990). Although a higher incidence of neoplasms was reported in a few $T$. cruzi-infected heart transplant recipients, no increase in incidence in human lymphoma rates has been reported among the larger population of treated patients 


\section{TABLE II}

Clinical studies of etiological treatment in long-term follow-up of chronic Chagas disease, assessing efficacy using clinical outcomes, Argentina, 1994-2007

\begin{tabular}{|c|c|c|c|c|}
\hline Author & $\begin{array}{c}\text { Treated patients } \\
\mathrm{n}\end{array}$ & $\begin{array}{l}\text { Untreated patients } \\
\mathrm{n}\end{array}$ & $\begin{array}{c}\text { ECG changes } \\
\text { treated vs. untreated patients } \\
\%\end{array}$ & $\begin{array}{c}\text { Heart disease progression } \\
\text { treated vs. untreated patients } \\
\%\end{array}$ \\
\hline Viotti et al. (1994) & 131 & 70 & $4 / 0$ & $2 / 17$ \\
\hline Gallerano et al. (2000) & 535 & 668 & $14 / 34$ & $6 / 18$ \\
\hline Viotti et al. (2006b) & 283 & 283 & $5 / 16$ & $4 / 14$ \\
\hline Fabbro et al. (2007) & 54 & 57 & $4 / 16$ & - \\
\hline Total & 1,003 & 1,078 & $7 / 24$ & $4 / 16$ \\
\hline
\end{tabular}

in countries where the two drugs have been in use for decades (Kirchhoff 1993). Ultimately, definitive data on this issue are lacking.

Adequate management of side effects is necessary to carry out treatment as well as to diminish unfounded fears associated with the use of benznidazole (Sosa-Estani et al. 2004, Viotti et al. 2009).

\section{Prevention of transmission and reactivation}

To break the chain of T. cruzi transmission, it is hypothesised that etiological treatment of infected children, potential blood donors and women of reproductive age can prevent transmission related to congenital transmission of the parasite (Sosa-Estani \& Segura 2006). However, to this point, etiological treatment with currently available drugs is not recommended for pregnant women (PAHO 1999).

Conversely, immunocompromise due to immunosuppressive therapies (Diez et al. 2007) and the spread of HIV/AIDS increases the risk of reactivation in patients with chronic infection (Cordova et al. 2008). Even though the effectiveness of etiological treatment for the control of reactivation episodes has been demonstrated, it is necessary to gather evidence as to whether preventive treatment is effective in patients with no signs of clinical reactivation who have altered immunological parameters (de Andrade Nishioka 2000). Some protocols recommend treating organ donors infected with $T$. cruzi to reduce the risk of transmission by transplantation (Altclas et al. 2005).

\section{New ways to address old needs}

During the past decade, numerous pharmacological studies have demonstrated the existence of significant pharmacokinetic and pharmacodynamic differences between adults and children (Reed 1999, Standing \& Tuleu 2005) and studies describing the kinetics of benznidazole are being carrying out (Garcia-Bournissen et al. 2009). Every year, the National Chagas Programs detect thousands of children infected in the chronic or earlier stages who require treatment. At this time, the only trypanocidal chemotherapeutic drugs available for $\mathrm{CD}$ are in solid dosage forms; therefore, pediatric formulations are still needed (Sosa-Estani et al. 2005). Studies are being conducted to create new formulations in solution (Lamas et al. 2006), suspension, and solid dissolvable tablet forms in pediatric concentrations (DNDi 2009).

Research on treatment alternatives should be targeted towards new drugs that allow shorter treatment courses with fewer adverse reactions and towards the improvement of tools to confirm cure after patients receive treatment during the chronic phase. Some strategies, such as compound screens, are being used for looking for new treatments (Urbina et al. 1998, Garzoni et al. 2004, Hudock et al. 2006, Ferraz et al. 2007) as complement to develop new compounds (DNDi 2009). Combinations of compounds with different mechanisms of action have also been mentioned as another way to look for new treatment alternatives (Banaim et al. 2006, Croft 2008, Francisco et al. 2008).

Recommendations for appropriate care of patients are increasing, putting the emphasis of care on the Primary Health Care System and using other levels of care when necessary (PAHO/WHO 2005). Additionally, psychological aspects should be incorporated into patient care (de Oliveira 2006, Villa et al. 2007). The health system must implement all currently approved and issued recommendations (PAHO/WHO 2006, Jannin \& Villa 2007).

Recently, the Minister of Health of Argentina (2007) approved a new health care system with a mandatory protocol for the care of infected patients (Public, Social Security, Health and Private Insurance) to provide the specific care needed, including etiological treatment when it is recommended by the official guidelines of the Health Ministry.

Based on the current disease understanding, there is consensus that every patient infected with $T$. cruzi during the early chronic infection phase (i.e., infected children under 16 years old) must be treated, and there is a trend towards offering treatment to adult patients with reactive anti-T. cruzi serology. Treatment can cure infection and reduce or prevent the progression to Chagas related heart disease/cardiomyopathy. The search for better drugs to find a solution for the eight million infected people is one challenge that must be addressed. In the meantime, benznidazole and nifurtimox continue to be the only drugs approved as effective treatments for T. cruzi. 


\section{ACKNOWLEDGMENTS}

To Sarah Iribarren, PhD Student of University of Utah, College of Nursing and NIH Fogarty/International Clinical Research Scholar, for her assistance in the critical revising and editing of this manuscript.

\section{REFERENCES}

Abramo Orrego L, Lansetti JC, Bozzini JP, Wynne de Martini GJ 1980. Hemoculture as a diagnostic method in Chagas disease. Medicina (B Aires) 40 (Suppl. 1): 56-62.

Albareda MC, Laucella SA, Alvarez MG, Armenti AH, Bertochi G, Tarleton RL, Postan M 2006. Trypanosoma cruzi modulates the profile of memory $\mathrm{CD} 8^{+} \mathrm{T}$ cells in chronic Chagas' disease patients. Int Immunol 18: 465-471.

Almeida IC, Pereira-Chioccola VL, Piovezam AG, Silsa LS, Velazquez E, Fragata AA, Segura EL, Sosa Estani S, Travassos LR 1999. Criterium of serological cure in treated chronic chagasic patients by chemoluminiscent immunoassay using Trypanosoma cruzi trypomastigote mucins. Medicina (B Aires) 59 (Suppl. III): 16.

Altcheh J, Corral R, Biancardi MA, Freilij H 2003. Anti-F2/3 antibodies as cure marker in children with congenital Trypanosoma cruzi infection. Medicina (B Aires) 63: 37-40.

Altclas J, Sinagra A, Dictar M, Luna C, Verón MT, De Rissio AM, García MM, Salgueira C, Riarte A 2005. Chagas disease in bone marrow transplantation: an approach to preemptive therapy. Bone Marrow Transplant 36: 123-129.

Alvarez M, Cerisola JA, Rohweder RW 1968. Test de inmunofluorescencia para el diagnóstico de la enfermedad de Chagas. Bol Chil Parasitol 23: 4-8.

Apt W, Arribada A, Zulantay I, Solari A, Sánchez G, Mundaca K, Coronado X, Rodríguez J, Gil LC, Osuna A 2005. Itraconazole or allopurinol in the treatment of chronic American trypanosomiasis: the results of clinical and parasitological examinations 11 years post-treatment. Ann Trop Med Parasitol 99: 733-741.

Avila HA, Sigman DS, Cohen LM, Millikan RC, Simpson L 1991. Polymerase chain reaction amplification of Trypanosoma cruzi kinetoplast minicircle DNA isolated from whole blood lysates: diagnosis of chronic Chagas' disease. Mol Biochem Parasitol 48: 211-221.

Benaim G, Sanders JM, Garcia-Marchan Y, Colina C, Lira R, Caldera AR, Payares G, Sanoja C, Burgos JM, Leon-Rossell A, Concepcion JL, Schijman AG, Levin M, Oldfield E, Urbina JA 2006. Amiodarone has intrinsic anti-Trypanosoma cruzi activity and acts synergistically with posaconazole. J Med Chem 49: 892-899.

Bern C, Montgomery SP, Herwaldt BL, Rassi A Jr, Marin-Neto JA, Dantas RO, Maguire JH, Acquatella H, Morillo C, Kirchhoff LV, Gilman RH, Reyes PA, Salvatella R, Moore AC 2007. Evaluation and treatment of Chagas disease in the United States: a systematic review. JAMA 298: 2171-2181.

Brener Z 1984. Recent advances in the chemotherapy of Chagas disease. Mem Inst Oswaldo Cruz 79: 149-155.

Britto C, Cardoso MA, Vanni CM, Hasslocher-Moreno A, Xavier SS, Oelemann W, Santoro A, Pirmez C, Morel CM, Wincker P 1995. Polymerase chain reaction detection of Trypanosoma cruzi in human blood samples as a tool for diagnosis and treatment evaluation. Parasitology 110: 241-247.

Bustamante JM, Bixby LM, Tarleton RL 2008. Drug-induced cure drives conversion to a stable and protective $\mathrm{CD} 8^{+} \mathrm{T}$ central memory response in chronic Chagas disease. Nat Med 14: 542-550.
Caballero ZC, Sousa OE, Marques WP, Saez-Alquezar A, Umezawa ES 2007. Evaluation of serological tests to identify Trypanosoma cruzi infection in humans and determine crossreactivity with Trypanosoma rangeli and Leishmania spp. Clin Vaccine Immunol 14: 1045-1049.

Camargo ME, Segura EL, Kagan IG, Souza JM, Carvalheiro Jda R, Yanovsky JF, Guimarães MC 1986. Three years of collaboration on the standardization of Chagas' disease serodiagnosis in the Americas: an appraisal. Bull Pan Am Health Organ 20: 233-244.

Cançado JR 1999. Criteria of Chagas disease cure. Mem Inst Oswaldo Cruz 94: 331-335.

Cançado JR 2002. Long term evaluation of etiological treatment of Chagas disease with benznidazole. Rev Inst Med Trop Sao Paulo 44: 29-37.

Cerisola JA 1977. Chemotherapy of Chagas' infection in man. Scientific Publication PAHO 347: 35-47.

Cerisola JA, Alvarez M, Lugones H, Rebosolán JB 1969. Sensitivity of serological tests in the diagnosis of Chagas' disease Bol Chil Parasitol 24: 2-8.

Cerisola JA, Fatala Chaben M, Lazzari JO 1962. Hemagglutination test for the diagnosis of Chagas' disease. Prensa Med Argent 49: 1761-1767.

Cerisola JA, Neves da Silva N, Prata A, Schenone H, Rohwedder R 1977. Evaluation of the efficacy of nifurtimox in chronic human chagasic infection by using xenodiagnosis. Bol Chil Parasitol 32: 51-62.

Cerisola JA, Rohwedder RW, Del Prado CE 1971. Yield of xenodiagnosis in human chronic Chagas' infection using nymphs of different species of triatomid bugs. Bol Chil Parasitol 26: 57-58.

Cerisola JA, Rosenbaum MB 1958. Complement-fixation reaction in the diagnosis of Chagas' disease. I. Technic. Prensa Med Argent 45: 1454-1463.

Chagas C 1911. Nova entidade mórbida do homem. Resumo geral dos estudos etiológicos e clínicos. Mem Inst Oswaldo Cruz 3: 219275.

Chiale PA, Halpern MS, Nau GJ, Tambussi AM, Przybylski J, Lázzari JO, Elizari MV, Rosenbaum MB 1984. Efficacy of amiodarone during long-term treatment of malignant ventricular arrhythmias in patients with chronic chagasic myocarditis. $\mathrm{Am}$ Heart J 107: 656-665.

Cordova E, Boschi A, Ambrosioni J, Cudos C, Corti M 2008. Reactivation of Chagas disease with central nervous system involvement in HIV-infected patients in Argentina, 1992-2007. Int J Infect Dis 12: 587-592.

Cossio PM, Diez C, Szarfman A, Kreutzer E, Candiolo B, Arana RM 1974. Chagasic cardiopathy. Demonstration of a serum gamma globulin factor which reacts with endocardium and vascular structures. Circulation 49: 13-21.

Croft SL 2008. Kinetoplastida: new therapeutic strategies. Parasite 15: 522-527.

Cunha-Neto E, Duranti M, Gruber A, Zingales B, De Messias I, Stolf N, Bellotti G, Patarroyo ME, Pilleggi F, Kalil J 1995. Autoimmunity in Chagas' disease cardiopathy: biological relevance of a cardiac myosin-specific epitope cross-reactive to an immunodominant Trypanosoma cruzi antigen. Proc Natl Acad Sci USA 92: 3541-3545.

Cura EN, Ruiz AM, Velazquez E, Malagrino N, Orn A, Segura EL 1993. Estandarización de un kit de confirmación (FATALAKIT) para el inmunodiagnóstico de la infección por el Trypanosoma cruzi. Medicina (B Aires) 53: 82. 
de Andrade ALS, Zicker F, de Oliveira RM, Almeida Silva S, Luquetti A, Travassos LR, Almeida IC, de Andrade SS, de Andrade JG, Martelli CM 1996. Randomosed trial of efficacy of benznidazole in treatment of early Trypanosoma cruzi infection. Lancet 348: 1407-1413.

de Andrade Nishioka S 2000. Primary chemoprophylaxis in the reactivation of Chagas' disease with benznidazole in chronic chagasic patients under immunosuppressive corticosteroid therapy: is there evidence for its recommendation? Rev Soc Bras Med Trop 33: $83-85$.

de Castro AM, Luquetti AO, Rassi A, Chiari E, da Cunha Galvão LM 2006. Detection of parasitemia profiles by blood culture after treatment of human chronic Trypanosoma cruzi infection. Parasitol Res 99: 379-383.

de Mecca MM, Bartel LC, de Castro CR, Castro JA 2008. Benznidazole biotransformation in rat heart microsomal fraction without observable ultrastructural alterations: comparison to Nifurtimoxinduced cardiac effects. Mem Inst Oswaldo Cruz 103: 549-553.

de Oliveira W Jr 2006. Depression and quality of life in Chagas patients. Rev Soc Bras Med Trop 39 (Suppl. 3): 130-132.

Diez M, Favaloro L, Bertolotti A, Burgos JM, Vigliano C, Lastra MP, Levin MJ, Arnedo A, Nagel C, Schijman AG, Favaloro RR 2007. Usefulness of PCR strategies for early diagnosis of Chagas' disease reactivation and treatment follow-up in heart transplantation. Am J Transplant 7: 1633-1640.

DNDi - Drugs for Neglected Diseases Initiatives 2009. New drugs for neglected diseases new hope for forgotten patients. Slide $\mathrm{n}^{\mathrm{o}}$ 8. Available from: http://www.dndina.org/Downloads/DNDi North_America.pdf. [cited 2009 Mar 10].

Dos Santos FM, Caldas S, de Assis Cáu SB, Crepalde GP, de Lana M, Machado-Coelho GL, Veloso VM, Bahia MT 2008. Trypanosoma cruzi: induction of benznidazole resistance in vivo and its modulation by in vitro culturing and mice infection. Exp Parasitol 120: 385-390.

Duarte AM, de Andrade HM, do Monte SJ, de Toledo Vde P, Guimarães TM 2006. Assessment of chemiluminescence and PCR effectiveness in relation to conventional serological tests for the diagnosis of Chagas' disease. Rev Soc Bras Med Trop 39: 385-387.

Fabbro D, Arias E, Streiger M, Bizai ML, del Barco M, Amicone NA 2007. Trypanocide treatment among adults with chronic Chagas disease living in Santa Fe City (Argentina), over a mean followup of 21 years: parasitological, serological and clinical evolution. Rev Soc Bras Med Trop 40: 1-10.

Feldman AM, McNemara D 2000. Myocarditis. N Engl J Med 343: 1388-1398.

Ferraz ML, Gazzinelli RT, Alves RO, Urbina JA, Romanha AJ 2007. The anti-Trypanosoma cruzi activity of posaconazole in a murine model of acute Chagas' disease is less dependent on gamma interferon than that of benznidazole. Antimicrob Agents Chemother 51: $1359-1364$.

Fragata Filho AA, da Silva MA, Boainain E 1995. Ethiologic treatment of acute and chronic Chagas' disease. São Paulo Med J 113: 867-872.

Francisco AF, de Abreu Vieira PM, Arantes JM, Pedrosa ML, Martins HR, Silva M, Veloso VM, de Lana M, Bahia MT, Tafuri WL, Carneiro CM 2008. Trypanosoma cruzi: effect of benznidazole therapy combined with the iron chelator desferrioxamine in infected mice. Exp Parasitol 120: 314-319.

Gallerano RR, Marr JJ, Sosa RR 1990. Therapeutic efficacy of allopurinol in patients with chronic Chagas disease. Am J Med Hyg 43: 159-166.
Gallerano RR, Sosa RR 2000. Interventional study in the natural evolution of Chagas disease. Evaluation of specific antiparasitic treatment. Retrospective-prospective study of antiparasitic therapy. Rev Fac Cien Med Univ Nac Cordoba 57: 135-162.

Galvão LM, Chiari E, Macedo AM, Luquetti AO, Silva SA, Andrade AL 2003. PCR assay for monitoring Trypanosoma cruzi parasitemia in childhood after specific chemotherapy. J Clin Microbiol 41: 5066-5070.

Galvão LMC, Nunes RMB ,Cançado JR, Krettli AU 1993. Lytic antibody as a means of assessing cure after treatment of Chagas disease: a 10 years follow-up study. Trans $R$ Soc Trop Med Hyg 87: $220-223$.

Ganzinelli S, Borda E, Joensen L, Sterin-Borda L 2008. Chagasic antibodies induce cardiac COX-2/iNOS mRNA expression with PGE(2)/NO production. Int J Cardiol 134: 212-223.

Garcia-Bournissen F, Altcheh J, Giglio N, Mastrantonio G, Della Védova CO, Koren G 2009. Pediatric clinical pharmacology studies in Chagas disease: focus on Argentina. Paediatr Drugs 11: 33-37.

Garzoni LR, Waghabi MC, Baptista MM, de Castro SL, Meirelles Mde N, Britto CC, Docampo R, Oldfield E, Urbina JA 2004. Antiparasitic activity of risedronate in a murine model of acute Chagas' disease. Int J Antimicrob Agents 23: 286-290.

Gascón J, Albajar P, Cañas E, Flores M, Gómez i Prat J, Herrera RN, Lafuente CA, Luciardi HL, Moncayo A, Molina L, Muñoz J, Puente S, Sanz G, Treviño B, Sergio-Salles X 2007. Diagnóstico, manejo y tratamiento de la cardiopatía chagásica crónica en áreas donde la infección por Trypanosoma cruzi no es endémica. Rev Esp Cardiol 60: 285-293.

Gorla NB, Ledesma OS, Barbieri GP, Larripa IB 1989. Thirteenfold increase of chromosomal aberrations nonrandomly distributed in chagasic children treated with nifurtimox. Mutat Res 224: 263-267.

Hudock MP, Sanz-Rodriguez CE, Song Y, Chan JM, Zhang Y, Odeh S, Kosztowski T, Leon-Rossell A, Concepcion JL, Yardley V, Croft SL, Urbina JA, Oldfield E 2006. Inhibition of Trypanosoma cruzi hexokinase by bisphosphonates. J Med Chem 49: 215-223.

Jannin J, Villa L 2007. An overview of Chagas disease treatment. Mem Inst Oswaldo Cruz 102 (Suppl. I): 95-97.

Jones EM, Colley DG, Tostes S, Lopes ER, Vnencak-Jones CL, McCurley TL 1993. Amplification of a T. cruzi DNA sequence of inflammatory lesions in human chagasic cardiomyopathy. $\mathrm{Am} J$ Trop Med Hyg 48: 348-357.

Kierszenbaum F 1999. Chagas' disease and the autoimmunity hypothesis. Clin Microbiol Rev 12: 210-223.

Kirchhoff LV 1993. Chagas disease: American trypanosomiasis. Infect Dis Clin North Am 7: 487-502.

Krautz GM, Galvão LM, Cançado JR, Guevara-Espinoza A, Ouaissi A, Krettli AU 1995. Use of a 24-Kilodalton Trypanosoma cruzi recombinant protein to monitor cure of human Chagas' disease. J Clin Microbiol 33: 2086-2090.

Kuschnir E, Sgammini H, Castro R, Evequoz C, Ledesma R, Brunetto J 1985. Valoración de la función cardiaca por angiografía radioisotópica, en pacientes con cardiopatía chagásica crónica. Arq Bras Cardiol 45: 249-56.

Lamas MC, Villaggi L, Nocito I, Bassani G, Leonardi D, Pascutti F, Serra E, Salomón CJ 2006. Development of parenteral formulations and evaluation of the biological activity of the trypanocide drug benznidazole. Int J Pharm 307: 239-243.

Laucella S, De Titto EH, Segura EL, Orn A, Rottenberg ME 1996. Soluble cell adhesion molecules in human Chagas' disease: association with disease severity and stage of infection. Am J Trop Med Hyg 55: 629-634. 
Laucella SA, Postan M, Martin D, Hubby Fralish B, Albareda MC, Alvarez MG, Lococo B, Barbieri G, Viotti RJ, Tarleton RL 2004. Frequency of interferon- gamma-producing $\mathrm{T}$ cells specific for Trypanosoma cruzi inversely correlates with disease severity in chronic human Chagas disease. Clin Infect Dis 189: 909-918.

Laucella SA, Segura EL, Riarte A, Sosa Estani S 1999. Soluble platelet selectin (s-P-Selectin) and soluble vascular adhesion molecule-1 (s-VCAM-1). Decrease during therapy with benznidazole in children with Indeterminate form of Chagas' disease. Clin Exp Immunol 118: 423-427.

Lauria-Pires L, Braga MS, Vexenat AC, Nitz N, Simões-Barbosa A, Tinoco DL, Teixeira AR 2000. Progressive chronic Chagas' heart disease 10 years after treatment with anti-Trypanosoma cruzi nitroderivatives. Am J Trop Med Hyg 63: 111-118.

Lazzari JO, Pereira M, Antunes CM, Guimarães A, Moncayo A, Chávez Domínguez R, Hernández Pieretti O, Macedo V, Rassi A, Maguire J, Romero A 1998. Diagnostic electrocardiography in epidemiological studies of Chagas' disease: multicenter evaluation of a standardized method. Rev Panam Salud Publica 4: 317-330.

Luquetti AO, Ponce C, Ponce E, Esfandiari J, Schijman A, Revollo S, Anez N, Zingales B, Ramgel-Aldao R, Gonzalez A, Levin MJ, Umezawa ES, Franco da Silveira J 2003. Chagas' disease diagnosis: a multicentric evaluation of Chagas Stat-Pak, a rapid immunochromatographic assay with recombinant proteins of Trypanosoma cruzi. Diagn Microbiol Infect Dis 46: 265-271.

Manzullo E 2001. Tratamiento de la enfermedad de Chagas en adultos. Abstract. Simposio de Enfermedad de Chagas. In XX Congreso Nacional de Cardiología. Federación Argentina de Cardiología, Córdoba.

Marin-Neto JA, Cunha-Neto E, Maciel BC, Simões MV 2007. Pathogenesis of chronic Chagas heart disease. Circulation 115: 1109-1123.

Marin-Neto JA, Rassi A Jr, Morillo CA, Avezum A, Connolly SJ, Sosa-Estani S, Rosas F, Yusuf S, BENEFIT Investigators 2008. Rationale and design of a randomized placebo-controlled trial assessing the effects of etiologic treatment in Chagas' cardiomyopathy: the BENznidazole Evaluation For Interrupting Trypanosomiasis (BENEFIT). Am Heart $J$ 156: 37-43.

Moretti E, Cervetta L, Basso B, Castro I, Santamarina N 1998. Chronic Chagas' disease: effects of treatment in the levels of antibodies to crude and partially purified Trypanosoma cruzi antigens. Bol Chil Parasitol 53: 3-9.

Morote S, Escriba JM, Garcia G, Roddy P, Albajar-Viñas P, Lima MA 2008. Tratamiento etiológico, efectos secundarios y seroconversión en pacientes con infección por el Trypanosoma cruzi. Experiencia de dos proyectos en Honduras y Guatemala. Enf Emerg 10 (Suppl. 1): 33-39.

Moya PR, Trombotto GT 1988. Chagas' disease: clastogenic effect of nifurtimox and benznidazole in children. Medicina (B Aires) 48: 487-491.

MSA - Ministerio de Salud de Argentina. Guías para la atención al paciente infectado con Trypanosoma cruzi (enfermedad de Chagas) 2006. Available from: http://www.msal.gov.ar/chagas/home.htm. [cited May 17 2009].

Muniz J, Freitas G 1944. Contribuição para o diagnóstico da doença de Chagas pelas reações de imunidade. II - Isolamento de polissacarídeos de Schizotrypanum cruzi e de outros tripanosomídeos, seu comportamento nas reações de precipitação, de fixação do complemento e de hipersensibilidade. Os "tests" de floculação (sublimado e formol-gel). Rev Bras Biol 4: 421-438.

Murta SM, Gazzinelli RT, Brener Z, Romanha AJ 1998. Molecular characterization of susceptible and naturally resistant strains of
Trypanosoma cruzi to benznidazole and nifurtimox. Mol Biochem Parasitol 93: 203-214.

PAHO - Pan American Health Organization 1999. Tratamiento etiológico de la enfermedad de Chagas. Conclusiones de una consulta técnica. OPS/HCP/HCT/140/99. Available from: http://www. paho.org/Spanish/AD/DPC/CD/chagas.pdf. [cited 2009 Mar 1].

PAHO - Pan American Health Organization 2005. Consulta técnica regional OPS/MSF sobre organización y estructura de la atención médica del enfermo o infectado por Trypanosoma cruzi (enfermedad de Chagas). Available from: www.paho.org/Spanish/AD/ DPC/CD/dch-consulta-ops-msf-2005.pdf. [cited 2009 Mar 1].

PAHO-WHO 2006. Estimación cuantitativa de la enfermedad de Chagas en las Américas. OPS/HDM/CD/425-06.

Pedreira de Freitas JL 1950. Xenodiagnosis performed in wild and domestic vectors of Trypanosoma cruzi in a locality endemic to Chagas' disease in the state of São Paulo. Hospital (RJ) 38: 521-529.

Petti MA, Viotti R, Armenti A, Bertocchi G, Lococo B, Alvarez MG, Vigliano C 2008. Predictor of heart failure in chronic chagasic cardiomyopathy with asymptomatic left ventricular dysfunction. Rev Esp Cardiol 61: 116-122.

Pinto Dias JC 2006. The treatment of Chagas disease (South American trypanosomiasis). Ann Intern Med 144: 772-774.

Ponce C, Ponce E, Vinelli E, Montoya A, de Aguilar V, Gonzalez A, Zingales B, Rangel-Aldao R, Levin MJ, Esfandiari J, Umezawa ES, Luquetti AO, da Silveira JF 2005. Validation of a rapid and reliable test for diagnosis of Chagas' disease by detection of Trypanosoma cruzi-specific antibodies in blood of donors and patients in Central America. J Clin Microbiol 43: 5065-5068.

Rassi A, Luquetti AO, Rassi A Jr, Rassi GG, Rassi SG, Da Silva IG, Rassi AG 2007. Specific treatment for Trypanosoma cruzi: lack of efficacy of allopurinol in the human chronic phase of Chagas disease. Am J Trop Med Hyg 76: 58-61.

Rassi A Jr, Rassi A, Little WC, Xavier SS, Rassi SG, Rassi AG, Rassi GG, Hasslocher-Moreno A, Sousa AS, Scanavacca MI 2006. Development and validation of a simple risk score for predicting mortality in Chagas' heart disease. N Engl J Med 355: 799-808.

Reed M 1999. Optimal sampling theory: an overview of its application to pharmacokinetics studies in infants and children. Pediatrics 104: 627-632.

Reyes PA, Vallejo M 2005. Trypanocidal drugs for late stage, symptomatic Chagas disease (Trypanosoma cruzi infection). Cochrane Database Syst Rev 19: CD004102.

Riarte A, Prado N, Luna C, Velázquez E, AM De Rissio, Malagrino N, Martín Garcia M, Hernández Y, Echeverri ME, Sinagra A, Laucella S, Esteva MI, Ruiz AM 2005. Tratamiento etiológico con benznidazol (BZ) en pacientes adultos en diferentes estadios de la enfermedad de Chagas crónica. Un ensayo clínico aleatorizado (ECA). In VII Congreso Argentino de Protozoología y Enfermedades Parasitarias, SAP 2005, Mendoza, Summary Book MR 5, p. 30-31.

Rosenbaum MB 1964. Chagasic myocardiopathy. Prog Cardiovasc Dis 7: 199-225.

Rosenbaum MB, Cerisola JA 1961. Epidemiology of Chagas' disease in the Argentine Republic. Hospital (RJ) 60: 55-100.

Russomando G, de Tomassone MM, de Guillen I, Acosta N, Vera N, Almiron M, Candia N, Calcena MF, Figueredo A 1998. Treatment of congenital Chagas' disease diagnosed and followed up by the polymerase chain reaction. Am J Trop Med Hyg 59: 487-491.

Sánchez G, Coronado X, Zulantay I, Apt W, Gajardo M, Solari S, Venegas J 2005. Monitoring the efficacy of specific treatment in 
chronic Chagas disease by polymerase chain reaction and flow cytometry analysis. Parasite 12: 353-357.

Sánchez Negrette O, Sánchez Valdéz FJ, Lacunza CD, García Bustos MF, Mora MC, Uncos AD, Basombrío MA 2008. Serological evaluation of specific-antibody levels in patients treated for chronic Chagas' disease. Clin Vaccine Immunol 15: 297-302.

Schenone H, Alfaro E, Reyes H, Taucher E 1968. Value of xenodiagnosis in chronic chagasic infection. Bol Chil Parasitol 23: $149-154$

Schijman AG, Altcheh J, Burgos JM, Biancardi M, Bisio M, Levin MJ, Freilij H 2003. Aetiological treatment of congenital Chagas' disease diagnosed and monitored by the polymerase chain reaction. J Antimicrob Chemother 52: 441-449.

Schijman AG, Vigliano C, Burgos J, Favaloro R, Perrone S, Laguens R, Levin MJ 2000. Early diagnosis of recurrence of Trypanosoma cruzi infection by polymerase chain reaction after heart transplantation of a chronic Chagas' heart disease patient. $J$ Heart Lung Transplant 19: 1114-1117.

Schijman AG, Vigliano CA, Viotti RJ, Burgos JM, Brandariz S, Lococo BE, Leze MI, Armenti HA, Levin MJ 2004. Trypanosoma cruzi DNA in cardiac lesions of Argentinean patients with end-stage chronic chagas heart disease. Am J Trop Med Hyg 70: 210-220.

Segura EL, Cura EN, Estani SA, Andrade J, Lansetti JC, de Rissio AM, Campanini A, Blanco SB, Gurtler RE, Alvarez M 2000. Long-term effects of a nationwide control program on the seropositivity for Trypanosoma cruzi infection in young men from Argentina. Am J Trop Med Hyg 62: 353-362.

Silber AM, Búa J, Porcel BM, Segura EL, Ruiz AM 1997. Trypanosoma cruzi: specific detection of parasites by PCR in infected humans and vectors using a set of primers (BP1/BP2) targeted to a nuclear DNA sequence. Exp Parasitol 85: 225-232.

Solari A, Ortiz S, Soto A, Arancibia C, Campillay R, Contreras M, Salinas P, Rojas A, Schenone H 2001. Treatment of Trypanosoma cruzi-infected children with nifurtimox: a three years follow-up by PCR. J Antimicrob Chemother 48: 515-519.

Sosa-Estani S 2005. Transmisión connatal del Trypanosoma cruzi en Argentina. Rev Soc Bras Med Trop 38: (Suppl. 2): 29-32.

Sosa-Estani S, Armenti, A, Araujo, G, Viotti R, Lococo B, Ruiz Vera B, Vigliano C, de Rissio AM, Segura EL 2004. Tratamiento de la enfermedad de Chagas con benznidazol y acido tióctico. Medicina (B Aires) 64: 1-6.

Sosa-Estani S, Belizan JM, Althabe F, Rubinstein A 2005. The need of a neonatal preparation for Chagas disease. PLoS Med 2: e387.

Sosa-Estani S, Gamboa-León MR, Del Cid-Lemus J, Althabe F, Alger J, Almendares O, Cafferata ML, Chippaux JP, Dumonteil E, Gibbons L, Padilla-Raygoza N, Schneider D, Belizán JM, Buekens P, Working Group 2008. Use of a rapid test on umbilical cord blood to screen for Trypanosoma cruzi infection in pregnant women in Argentina, Bolivia, Honduras and Mexico. Am J Trop Med Hyg 79: $755-759$

Sosa-Estani S, Herrera de Bravo B, Herrera de Bizzoto L, Canil S, Cura EN, Segura EL 2002. Evolución serológica a largo plazo en niños infectados por Trypanosoma cruzi que cursan fase clínica indeterminada, tratados con benznidazol. Available from: http:// www.fac.org.ar/fec/chagas2/llave/md8/md804/sosaes.htm, 2002. [updated 2000; cited 2009 Mar 15].

Sosa-Estani S, Segura EL 1999. Treatment of Trypanosoma cruzi infection in the indeterminate phase: experience and current guidelines in Argentina. Medicina (B Aires) 59 (Suppl. 2): $166-170$.
Sosa-Estani S, Segura EL 2006. Etiological treatment in patients infected by Trypanosoma cruzi: experiences in Argentina. Curr Opin Infect Dis 19: 583-587.

Sosa-Estani S, Segura EL, Ruiz AM, Velazquez E, Porcel BM, Yampotis C 1998. Chemotherapy with benznidazole in children in undetermined phase of Chagas disease. Am J Trop Med Hyg 59: 526-529.

Standing JF, Tuleu C 2005. Paediatric formulations - Getting to the heart of the problem. International J Pharm 300: 56-66.

Sterin-Borda L, Borda E 2000. Role of neurotransmitter autoantibodies in the pathogenesis of chagasic peripheral dysautonomia. Ann N Y Acad Sci 917: 273-280.

Storino R, Auger S, Caravello O, Urrutia MI, Sanmartino M, Jörg M 2002. Chagasic cardiopathy in endemic area versus sporadically infected patients. Rev Saude Publica 36: 755-758.

Storino R, Auger S, Wojdyla D, Urrutia M, Jörg M 1998. Análisis descriptivo multivariado de la enfermedad de Chagas en 2,260 pacientes. Rev Argent Cardiol 66: 17-39.

Streiger ML, del Barco ML, Fabbro DL, Arias ED, Amicone NA 2004. Longitudinal study and specific chemotherapy in children with chronic Chagas' disease, residing in a low endemicity area of Argentina. Rev Soc Bras Med Trop 37: 365-375.

TDR/WHO 2008. Workshop and symposium: standardization and validation of clinical use of PCR for Trypanosoma cruzi DNA detection in clinical Chagas. Available from: http://www.who. int $/ \mathrm{tdr} / \mathrm{svc} /$ news-events/events/tdr/chagas-pcr-workshop-symposium. [updated 2008; cited 2009 Mar 15].

TDR/WHO/PAHO, CDIA. Scientific Working Group on Chagas Disease, Sosa-Estani S, Lorca M, Altcheh J, Freilij H 2005. Therapeutic management of infection and acute disease. Introduction and reporters: sientific working group on Chagas disease. TDR, WHO/ PAHO, CDIA, Session 7: 61-67. Available from: http://cdiaec.uniandes.edu.co/Annex\%20C.pdf. [updated 2007; cited 2009 Mar 1].

Teixeira AR, Silva R, Cunha Neto E, Santana JM, Rizzo LV 1990. Malignant, non-Hodgkin's lymphomas in Tripanosoma cruzi-infected rabbits treated with nitroarenes. J Comp Pathol 103: 37-48.

Urbina JA, Payares G, Contreras LM, Liendo A, Sanoja C, Molina J, Piras M, Piras R, Perez N, Wincker P, Loebenberg D 1998. Antiproliferative effects and mechanism of action of SCH 56592 against Trypanosoma (Schizotrypanum) cruzi: in vitro and in vivo studies. Antimicrob Agents Chemother 42: 1771-1777.

Vattuone NH, Yanovsky JF 1971. Trypanosoma cruzi: agglutination activity of enzyme-treated epimastigotes. Exp Parasitol 30: 349-355.

Venegas J, Coñoepan W, Pichuantes S, Miranda S, Apt W, Arribada A, Zulantay I, Coronado X, Rodriguez J, Reyes E, Solari A, Sanchez G 2009. Differential distribution of Trypanosoma cruzi clones in human chronic chagasic cardiopathic and non-cardiopathic individuals. Acta Trop 109: 187-93.

Villa L, Morote S, Bernal O, Bulla D, Albajar-Vinas P 2007. Access to diagnosis and treatment of Chagas disease/infection in endemic and non-endemic countries in the XXI century. Mem Inst Oswaldo Cruz 102 (Suppl. I): 87-94.

Villar JC, Marin-Neto JA, Ebrahim S, Yusuf S 2002. Trypanocidal drugs for chronic asymptomatic Trypanosoma cruzi infection. Cochrane Database Syst Rev: CD003463.

Viotti R, Vigliano C, Alvarez MG, Lococo B, Petti M, Bertocchi G, Armenti A 2008. The impact of socioeconomic conditions on the evolution of chronic Chagas disease. Abstracts. In World Congress of Cardiology, Buenos Aires, May 18-21, 2008. Circulation 118: e177. 
Viotti R, Vigliano C, Armenti A, Segura EL 1994. Treatment of chronic Chagas' disease with benznidazole: clinical and serologic evolution of patients with long-term follow-up. Am Heart Journal 127: 151-161.

Viotti R, Vigliano C, Laucella S, Lococo B, Petti M, Bertocchi G, Ruiz Vera B, Armenti H 2004. Value of echocardiography for diagnosis and prognosis of chronic Chagas disease cardiomyopathy without heart failure. Heart 90: 655-660.

Viotti R, Vigliano C, Lococo B, Alvarez MG, Petti M, Bertocchi G, Armenti A 2009. Side effects of benznidazole as treatment in chronic Chagas disease: fears and realities. Expert Rev Anti Infect Ther 7: 157-163.

Viotti R, Vigliano C, Lococo B, Bertocchi G, Petti M, Alvarez MG, Postan M, Armenti A 2006a. Long-term cardiac outcomes of treating chronic Chagas disease with benznidazole versus no treatment: a nonrandomized trial. Ann Intern Med 144: 724-734.

Viotti R, Vigliano C, Lococo B, Petti M, Bertocchi G, Alvarez MG, Armenti A 2005. Clinical predictors of chronic chagasic myocarditis progression. Rev Esp Cardiol 58: 1037-1044.

Viotti R, Vigliano C, Lococo B, Petti M, Bertocchi G, De Cecco F, Alvarez MG, Laucella S, Armenti A 2006b. Exercise stress testing as a predictor of progression of early chronic Chagas heart disease. Heart 92: 403-404.

WHO - World Health Organization Expert Committee 2002. Control of Chagas disease. Brasilia, Brazil. WHO Technical Report Series 905: 29-35.

Zhang L, Tarleton RL 1999. Parasite persistence correlates with disease severity and localization in chronic Chagas' disease. J Infect Dis 180: 480-486. 